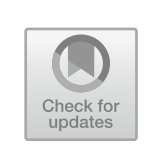

\title{
Ways of Reading: Cultural Revolution Reading Acts
}

What is the status of Cultural Revolution shouchaoben fiction within the Chinese literary and intellectual field? What role did manuscript fiction play during the Cultural Revolution in relation to other reading materials? What is their post-Mao legacy? This chapter examines which texts were read by whom during the Cultural Revolution, for what purpose, and what meaning was attributed to the various readings. Mapping the reading cosmos of the Cultural Revolution decade, I will provide an overview of the reading practices and the amount and diversity of texts and genres available at the time.

In the introduction to this book, I sketched the gap between an officially highly regulated literary and intellectual field and the blossoming of unofficial, even illegal, grassroots reading activities. Official literature had to adhere to the Maoist literary dogmas that had been established since the Yan'an years, including the three prominences, which resulted in clear-cut and flawless heroes and in plotlines that may seem dull to

This chapter was developed as part of the project "The Politics of Reading in the People's Republic of China (READCHINA)" which received funding from the European Research Council (ERC) under the European Union's Horizon 2020 research and innovation program (grant agreement No. 757365).

(C) The Author(s) 2021

L. Henningsen, Cultural Revolution Manuscripts, Chinese Literature and Culture in the World, https://doi.org/10.1007/978-3-030-73383-4_5 
today's readers as both the ubiquitous Cultural Revolution model works and the texts leave no doubt from the outset as to who is going to turn out as the "bad guy" and who the hero of the story. The purpose of these texts was to provide the audience with heroes to emulate in their own lives. Anything that did not conform to these rules, as well as any text regarded as suspicious, for reasons such as the wrong class background of the author, was censored. This censorship also extended to texts published in China between 1949 and 1966, to most Republican period authors (except for Lu Xun), to almost all literature from the Soviet Union as the former brother country had fallen from grace and with it most of its literature and to literature from western countries.

An entirely different picture arises in actual, albeit unofficial, reading practices. Urban educated youth, in particular, could read widely (Sun 2016; Zhao 2016a, b), even though doing so was dangerous. The chaos of the Cultural Revolution, both during the Red Guard movement of the early years and the rustication period that followed, provided readers with opportunities to read far beyond what the party center may have deemed acceptable. Some Red Guards did not destroy the books they obtained during house raids, but instead kept, read and circulated them. The libraries were closed, but, as they were not well-guarded, for some it became a kind of sport to break into them and steal books. The children of (high-level) cadres began to read the internal publications they found on their parents' bookshelves and to discuss these with their friends. With the rustication movement, these books traveled the country as the educated youth took the books along with them to the countryside. From there, the books circulated even further, both the original copies and handwritten copies, either of parts of the books or of the entire books. New texts were also produced; for example, some Red Guard factions would produce their own (mostly short-lived) newspapers (on this, see Yang Guobin 2016: 69-92; Volland 2003: 395-439). In opposition to official policies, Yu Luoke wrote and printed his political treatise "On Family Origin" in 1966, for which he would pay with his life (Yang Guobin 2016: 80-83; Shao 2015: 76-812, see also my elaborations in Chapter 1). Others joined literary salons, where they wrote and discussed poetry, while others wrote shouchaoben fiction. The actual reading cosmos thus consisted of more variety than officially intended (or desired). As a consequence, Cultural Revolution reading practices attest to a lively and varied literary and intellectual life, albeit one that was very heterogeneous, depending on the social position, family background and 
personal connections, on the particular geographical position, the literary, artistic and intellectual ambitions, desires and needs and the courage of those involved. After all, reading forbidden texts could lead to severe punishment.

The diversity of these readings and of actual reading practices represents a strong contrast vis-à-vis the egalitarianism and uniformity suggested by official literature and arts and propaganda. Moreover, these diverse intellectual, literary and artistic artifacts in turn laid the seeds for the development of the post-Cultural Revolutionary reform era. Reading practices, I argue, are a particularly valuable source for investigating literary developments as they provide an analytical focus on the audience and the effects of literary texts (be they aesthetic or social) and thus also provide an understanding of the popularity of certain texts. While this holds true for all literary developments worldwide, the particular context of the Maoist years adds another twist to this as reading was being heavily promoted through literacy classes and study groups. The normative function of reading had also been established during the seventeen years, and reading practices were therefore linked to intellectual and literary, as well as social, developments. During the Yan'an years, and to a larger extent after the establishment of the rule of the CCP in China, a decisive literary and cultural policy was enforced by the regime. Based on Mao's "Yan'an Talks", literature and art had to serve the interests of the party. This had consequences for authors, who in their writing had to make sure they followed the political and aesthetic rules set by the party (see Van Fleit Hang 2013; King 2013; Mittler 2012; Denton 2016; McDougall 1980). A "set of works considered classical" (Wagner 1995: 464) provided authors with models for their literary writing. The leadership expected authors to employ their works to reform and educate the laboring classes. However, this policy also impacted readers: as the authorities were convinced of the educational function of literature, readers in turn were trained to take literary heroes as models and emulate them in their behavior. This resulted in a particular normative way of reading, and in:

an expectation on the side of the readers, that literature would provide them with living models to emulate, an expectation again guided by the reading technique instilled through the schools and the various campaigns to emulate this or that literary or semi-literary hero or heroine. (Wagner 1995: 464) $)^{1}$ 
The repercussions of this mode of reading can be clearly seen in the sources discussed in this and the following chapter, both in accounts of real-life reading practices and in fictional texts.

Therefore, in this chapter I examine autobiographical accounts that focus on reading during the Cultural Revolution. This allows for a mapping of the readings considered meaningful within an individual's lifewriting. Methodologically, autobiographical sources are valuable because they provide access to grassroots practices and provide us with a plurality of individual voices, a plurality that is often invisible in the official record. Like all pieces of life-writing, these texts also need to be read with caution though: written after the fact, sometimes decades after the events being related, their truth-value has to be heavily scrutinized. Memory loss (particularly after a long lapse of time), purposeful misrepresentation of events (to fit the contemporary political situation or assumed expectations of a later readership) and outright distortion of the truth can reduce the truth-value of the texts. It must not be forgotten that autobiographical accounts are less about anything that is "objectively" true and instead more reflective of what the individual experienced as important and how an event, or a reading act, made sense within the overall framework of the individual's life. What is the agenda of the author in a piece of life-writing? What image of the self does he/she want to present in his/her account? How is he/she inscribing him/herself into current discourses? Is the autobiography a document about, as in the present case, the Cultural Revolution, or should it be treated as a document about the specific point in post-Mao China when it was written? Moreover, the experiences of those who chose not to write, or otherwise found no voice to narrate their lives, are missing from the picture. If something is absent from the sources, this does not necessarily mean it was not read widely at the time. Rather, such absence may have to do with biases, either in the choice of sources or in the world view and images of the self presented in the autobiographical sources. To counter (potential) shortcomings, I pursue a threefold approach, as follows. First, I propose a distant reading perspective that allows for a more diverse breadth in the sample. Second, I consciously investigate the blind spots in the sample through a close reading of the sources. Third, I propose integrating descriptions of reading acts and other intertextual references in shouchaoben fiction into the analysis to which I will proceed in the following chapter. 
In this chapter, combining close and distant readings of these autobiographical accounts, I argue that, first, continuity prevails: while the events of the Cultural Revolution represent a rupture in the lives of many individuals, many literary and intellectual practices can be related to earlier ones that they expand upon or modify, thus prefiguring developments commonly associated with the post-Cultural Revolution epoch. Second, reading practices are particularly useful for making this point: readings can continue to create meaning for their readers over long periods of time and thus they also continue to be discussed. Reading materials may also continue to circulate, albeit clandestinely (and being censored can even increase the respective text's attraction among readers). The particular normative mode of reading inscribed into readers' minds during the early Maoist years may even have increased the significance attributed to reading as readers would consciously search for models in literary texts that they could emulate in their own lives. Third, the variety of reading materials attests to readers' curiosity beyond their own living environment, including other parts of the world or periods of time. Reading practices thus attest to the fact that literary practices of the long 1970s ought to be considered within a transcultural context, i.e., within the realm of world literature that circulates globally through translations that gain relevance not only in their country of origin, but also in the recipient culture (Damrosch 2003). Fourth, the practices of reading of the Cultural Revolution testify to a particular fluidity in the demarcations between readers and authors of texts, not only in connection with shouchaoben fiction, but also in relation to other texts.

\section{Distant Reading: What MatTers? Popular Reading Materials}

What types of reading mattered most to readers during the Cultural Revolution? Which texts were most popular at the time? In scholarly literature, there are overviews as to which titles were allegedly the most influential, but sources for these claims are not always given (i.e. Wang 2014). As an alternative approach, I am proposing a distant reading of autobiographical texts about the Cultural Revolution that focus on reading experiences during the era. In this, I follow the distant reading approach proposed by Franco Moretti, who considers this approach a "specific form of knowledge" (Moretti 2007: 1). Moretti (2013) employs distant reading to track changes in literary developments over time, such as understanding the 
rise of the novel in different regions of the world with the aim of looking beyond established canons. My approach differs in two respects: that of size and direction. First, compared to Moretti, the sample here is relatively small. While I believe that the sources allow for a number of general observations, a significant increase in data may lead to readjustments on the level of details. Second, while Moretti is distant reading literary texts and their properties, the focus here is on reading itself, on the reading of literary and nonliterary texts.

To this end, in the "Worlds of Reading during China's long 1970s" project, we built the "ReadAct: Reading Act Database" (Henningsen and Paterson 2020) in which we recorded concrete reading acts as related in the sources in order to engage in quantitative and qualitative analyses. The "reading act" refers to interactions with texts in a broad sense, ranging from conventional reading, to borrowing, copying, learning by heart, discussing, criticizing or even taking a text as a model for one's own life. We sampled accounts by 95 authors, of whom 71 are male, 17 are female and for seven the gender could not be identified. The sample (data update July 30, 2019) consists of a broad range of texts, published within China and elsewhere, in print and online, between 1980 and 2016 (with the bulk of publications published after 1999), including both book-length autobiographies and shorter life-writing texts. These authors record 1054 reading acts, pointing to 415 identifiable authors and 234 concrete texts (fiction, nonfiction, poetry; Chinese and foreign; internal and open publication). These are discussed in different degrees of elaborateness, ranging from simple references to detailed descriptions of reading acts and their meaning for the respective individuals. Given that most of the texts are written by former educated youth, the majority of the sources cover the rustication period, starting at the end of 1968. While each individual mention of a text may be dismissed as mere anecdotal evidence, in sum, they can serve to make an argument about the (ascribed) popularity or importance of a certain text. For the compilation of the database, the autobiographical accounts were read in search for memories of interactions with texts, such as the reading, copying or sharing of a concrete text, as well as the reciting of a text memorized earlier in life or the indignation vented against a text. The database can thus be searched for titles and authors of texts read, for the readers, as well as for the type of interaction with a text, such as reading, copying, borrowing and much more. The distant reading findings discussed on 
the following pages represent the quantitative analysis of the contents of database.

As an overview, Fig. 5.1 presents the genres mentioned in the sources most frequently. Those genres with only one or two references are not included here.

From this overview fiction emerges as the most popular genre in the sample. The fact that poetry ranks second confirms the earlier observations about the popularity of poetry. This figure refers to the number of titles mentioned, but it does not provide information about the number of times an individual text is mentioned. Figure 5.2 lists the titles referred to most frequently in the sources, with five occurrences or more. This list roughly reproduces the numerical proportion observable in the genre overview as it includes solely fiction and books categorized as informational works.

This sample represents an astonishing breadth of titles: most are foreign titles (with only three Chinese titles, all premodern) and the majority originated from within the internal publishing system. Among these is Khrushchev's 1956 secret speech "On the Cult of Personality and its Consequences"; The Catcher in the Rye; On the Road; Aksyonov's Ticket to the Stars, a popular novel from the Soviet Union dealing with the aspirations of and search for a purpose in life by the young generation; Djilas' The New Class, which heavily criticized the suppressive new class

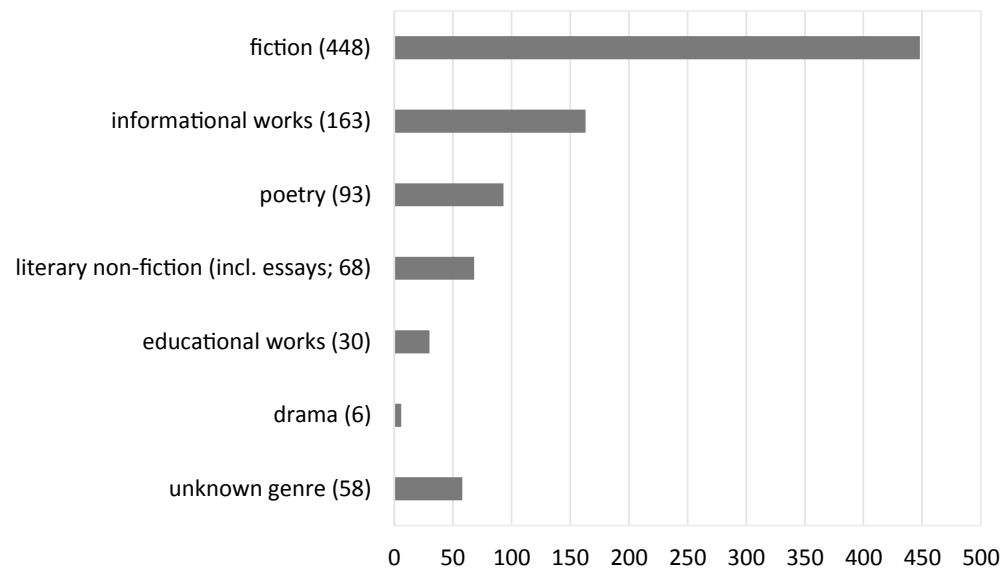

Fig. 5.1 Genres mentioned most frequently in autobiographical sources 


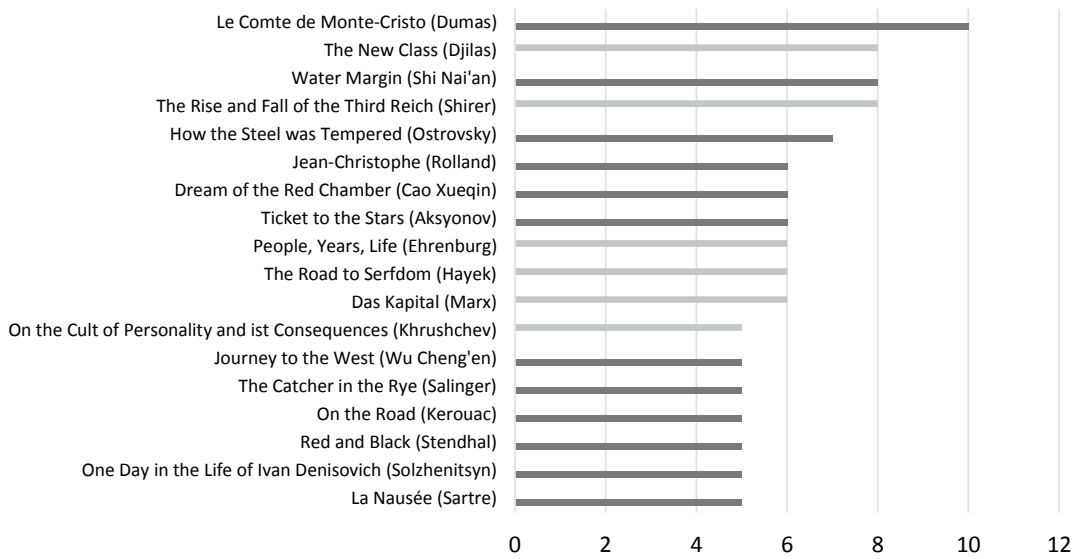

Fig. 5.2 Texts mentioned most frequently in autobiographical sources with light grey bars representing nonfiction and dark grey bars representing fiction

system that had come into being under the Soviet regime; Hayek's The Road to Serfdom that warns of tyranny that may be the result of central planning under socialism; William Shirer's The Rise and Fall of the Third Reich ${ }^{2}$; Ehrenburg's autobiography People, Years, Life; Solzhenizyn's One Day in the Life of Ivan Denisovich; and Sartre's La Nausée. Dream of the Red Chamber had been criticized since the early 1960s; Jean-Christophe by Romain Rolland had been translated into Chinese several times, but was criticized during the 1960s. Only six titles therefore did not entail censorship issues: How the Steel was Tempered, which counted among the "set of works considered classical" (Wagner 1995: 464) that were central to the practices of normative reading instilled into Chinese readers, Marx' Das Kapital, Water Margin, Stendhal's Red and Black, Journey to the West and Dumas' Le Comte de Monte-Cristo. Of these the latter two were promoted during the Cultural Revolution. Overall, thus, the majority of the titles are novels (12), five are factual texts with political content, and one is an autobiography. Conversely, poetry, the second most popular literary genre, is missing entirely from this list. Poems, however, do appear once titles with four reading acts in the database are considered:

- Three Hundred Tang Poems

- Baudelaire's poetry collection Les Fleurs du Mal 
- "Le Cimetière Marin" (Paul Valéry)

- War and Peace (Tolstoy)

- La Comédie Humaine (novel by Balzac)

- Wuthering Heights (Emily Brontë)

- Vierundzwanzig Stunden aus dem Leben einer Frau (Stefan Zweig)

- Red Crag (Luo Guangbin and Yang Yiyan)

- The Gadfly (Ethel Voynich)

- The Story of Zoya and Shura (Kosmodemyanskaya)

- Das Manifest der Kommunistischen Partei (The Manifesto of the Communist Party)

- Anti-Dübring (Engels and Marx)

- Dialektik der Natur (Engels)

- The State and the Revolution (Lenin)

- Khrushchev: A Career

- English 900

- A General Introduction to Psychoanalysis (no author).

This list confirms the observation that the majority of the titles were of foreign origin, but it slightly expands the sample by adding three items of poetry (Baudelaire, Valéry and Tang poetry), five political texts or treatises, two educational items (an English textbook and an introduction to psychoanalysis) and seven more novels: War and Peace; Red Crag (1961), a novel about the 1949 underground struggle of the CCP against the GMD; The Gadfly (1897 which is intertextually related to How the Steel was Tempered); The Story of Zoya and Shura, which was also widely propagated to Soviet and Chinese readers; and three novels of Western European origin: La Comédie Humaine, Wuthering Heights and Vierundzwanzig Stunden aus dem Leben einer Frau.

Figure 5.3 provides a still more diverse image of the Cultural Revolution reading cosmos. Here, the reading acts are represented in relation to the authors of texts. Other authors are added to the list who appear with more than one title. The changes in color intensity represent different titles, i.e., there are three titles by Dumas mentioned once and a third title mentioned ten times (the aforementioned Le Comte de Monte-Cristo); the poet Bei Dao (北岛 * 1949 , who appears in the database both as an author of texts read during the Cultural Revolution, and as the author of a post-Cultural Revolution autobiographical text) is represented with nine different titles, one of them mentioned twice, the other once. With Bei Dao, Guo Lusheng 郭路生 (*1948, pen name Shi Zhi 食指, himself 


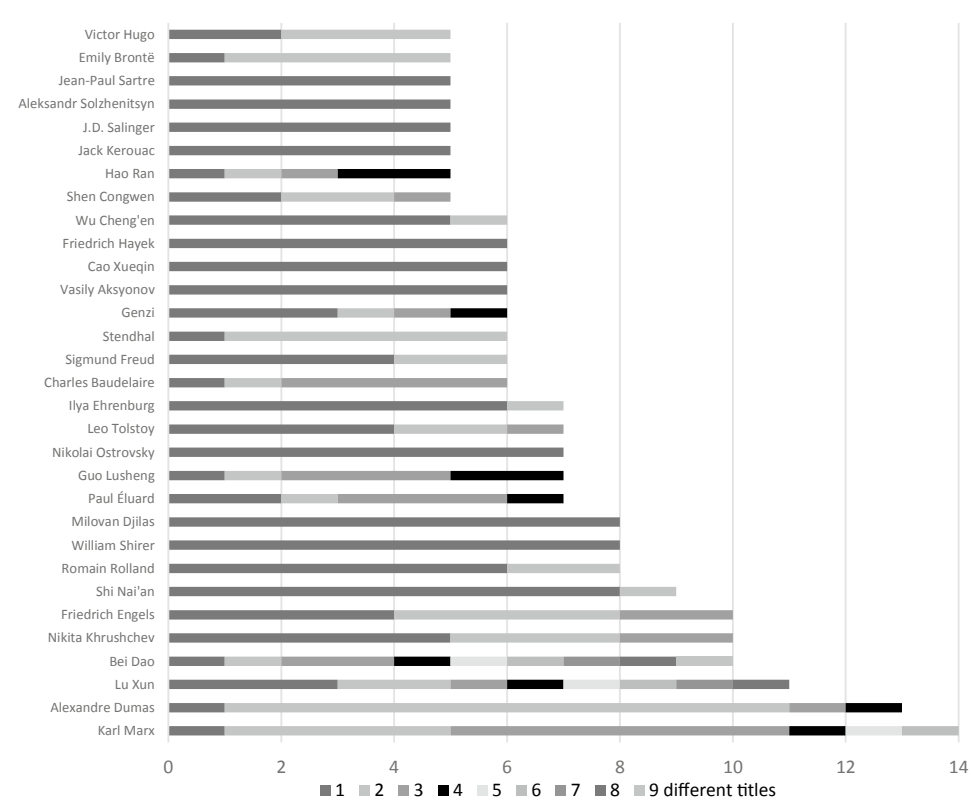

Fig. 5.3 Authors mentioned most frequently in autobiographical sources, excluding references to the works of Mao Zedong

sent down to the countryside) and Genzi 根子 ( ${ }^{*} 1951$, pen name of Yue Zhong 岳重), contemporary Chinese poetry gains a new weight in the sample as the references to these three poets who were active during the Cultural Revolution add up to 17 different titles. In some cases, the authors of autobiographies refer to having read a book by a certain author without providing a title. In the case of Emily Brontë, for example, there are four references to Wuthering Heights and one to an unknown title. This is likely a fifth reference to the famous novel, but as the source does not say so explicitly, it is recorded as an unknown title. Three more Chinese authors enter the sample as well: the Republican era author Shen Congwen who stopped writing literature from 1949, Hao Ran, author of the Cultural Revolution novel The Golden Road and Mao Zedong. For the sake of better readability of this chart, references to the latter do not appear: In our database, there are 33 references to 23 different titles written by him. The sheer amount and variety of titles are astonishing 
at first glance. On consideration, however, it serves as a neat illustration of the ubiquity of Mao Zedong and his words during the Cultural Revolution.

The breadth of the authors and titles considered meaningful in the autobiographical sources thus suggests that the 1970s were indeed quite varied in the choice of reading materials available, at least to some. The fact that the majority of authors are foreign is particularly noteworthy. This suggests, I argue, that readers during the Cultural Revolution were actively looking for foreign reading beyond the confines of what was deemed permissible by the CCP. (The lure of the forbidden may, in fact, have increased the appeal of these texts.) In their autobiographies, these readers thus create images of themselves and of the entire decade (considering these readings in sum) as open-minded and cosmopolitan. Texts from the realm of contemporary world literature (Kerouac, Salinger, Aksyonov, Djilas), alongside earlier canonical works, play a prominent role in this sample. Lu Xun, as I will demonstrate below, likewise attains a cosmopolitan aura. With these overviews, I have sketched which genres, texts and authors were among the most widely read within the 1970s worlds of reading, at least through the lens of autobiographical texts. But how popular were these readings? Were they liked or disliked? Were they read voluntarily or were they compulsory? What did readers remember afterward? How much would they later claim these readings impacted on their lives? How, then, were these reading materials read, and how did they matter?

\section{Close Reading: How Does It Matter, And Why?}

In order to discuss what mattered and how, this section begins with an excerpt by Shu Ting 舒婷 (*1952) in which she delineates her experiences of the Cultural Revolution along the lines of her reading practices. In a second step, I will then discuss how four of the authors that were shown to be particularly popular in Fig. 5.3 mattered to the autobiographers: $\mathrm{Lu}$ Xun, Romain Rolland, Salinger and Kerouac.

"Dang!" Something fell down and hit me on the eyebrow, I felt for it with my hand: it was a warm bullet. Above, my comrades-in-arms with their Red Guard armbands were storming the physics building, while I was reading Hugo's 1793, which was also about attack and defense, suffering and struggle, humiliation and indignation, which was also about truth, 
good and beauty. I was fully immersed inside a different world opened up within works of literature by Balzac, Tolstoy and Mark Twain. Though I still had a nightmare, in it I saw wooden boards weighing more than ten kilograms and blood pearls oozing out from iron wires, thus humiliation turned into a gloomy stream in the eyes of persons I honored. Soaked in sweat I would always awake from these dreams, gather some clothes and foods, take them to the imprisoned members of my family, and enter another nightmare which was full of rebuke and supercilious looks.

The golden dust on the surface of life peeled off, revealing its uneven truth. Only books could soothe me.

In 1969, I put an English textbook (my dream of going to university) and "A Transcription of Poems by Pushkin" 4 into my backpack and went to the countryside with others of my generation amidst heart-breaking sirens. On the platform and inside the carriage there was the sound of crying. I stared at contours of the mountains in the distance and thought to myself that the members of the Decembrist Revolt ${ }^{5}$ certainly did not cry on their way to exile. I wanted to go to Gorky's "university" there.

Life constantly educated my naïveté. The knowledge that this "university among the people" provided me with, however, widely surpassed any real university.

...

Thereupon, I took up the pen.

During these three years, I wrote diaries every day. Before returning to the city, I burned three volumes of my diaries. Some scattered pages that were preserved by luck, were later published in the first issue of Banyan Tree Essays (榕树丛刊).

I desperately copied poems, this also was a sort of exercise. At the time, I was crazy for Tagore's prose poems and for He Qifang's "Prophecy". As well as the works of Byron, Mickiewicz and Keats, there were also those of Yin $\mathrm{Fu}$, Zhu Ziqing and Ying Xiuren.

Moreover, there were letters. Writing and reading letters was an important part of the lives of the educated youth, it was my greatest pleasure. I still remember how, deeply worried, I would wait for that green post bag on the village road, and how hastily I would then sit down on the small bridge to read the letter. I wrote a poem for a female friend: "Start on [your] journey, beloved girl, the passage of life is free and broad...". This poem circulated and earned me some literary friends. They often sent books that they were interested in. I once spent a whole month locked behind the door reading Franz Mehring's "Biography of Marx" and also read the explanatory part of the four volumes of Mao's Selected Writings, although I never appeased the ghosts; with difficulty, I also read theoretical books such as "On the Aesthetic Education of Man" and "The Dialogues of 
Plato" and with ease forgot all about them again. Because of my friends' emphatic recommendation, I also purposely read some classical works, of which I liked best the ci-poems by Li Qingzhao and Qin Guan, as well as essays. (Shu Ting 1999 [1980]: 300-301)

Shu Ting can be regarded as representative of the educated youth, so this piece of life-writing may be considered exemplary, reflecting the reading cosmos of many of her contemporaries. Similar to other authors, Shu Ting mainly refers to foreign literature (with a focus on authors of modern fiction: Victor Hugo (1802-1885), Honoré de Balzac (17991850), Leo Tolstoy (1828-1910), Mark Twain (1835-1910) and Maxim Gorky (1868-1936), whose autobiography she refers to), poetry and essays. For essays she does not name any author, but for poetry she lists both foreign and Chinese authors. The Nobel Prize-winning author Rabindranath Tagore (1861-1941) is mentioned, along with European authors John Keats (1795-1821), George Byron (1788-1824) and the Polish poet Adam Mickiewicz (1798-1855, considered a national poet in Poland, Lithuania and Belarus), and Chinese poets of the early and mid-twentieth century: Yin Fu 殷夫 (1910-1931), Zhu Ziqing 朱自清 (1898-1948), Ying Xiuren 应修人 (1900-1933) and He Qifang 何其芳 (1912-1977). Two Chinese poets of earlier centuries (Li Qingzhao 李清 照, 1084-1155, and Qin Guan 秦观, 1049-1100) are mentioned, along with nonfictional readings from the ideological realm that Shu Ting made efforts to read: Franz Mehring's Biography of Marx, ${ }^{6}$ the explanatory part of the four volumes of Mao's Selected Writings, and older European texts: "The Dialogues of Plato" and "On the Aesthetic Education of Man”, which refers to Friedrich Schiller's Über die ästhetische Erziehung des Menschen, a treatise written in 1793 in epistolary form and dealing with Immanuel Kant's aesthetics and the failure of the French Revolution.

In her account, Shu Ting refers to poetry in great number and variety. This may be considered as reflective of the fact that she later became a respected poet herself, or simply that the Cultural Revolution was a decade of poetry, also taking into consideration the countless literary salons discussing poetry at the time and the overall popularity of poetry among the educated youth for reasons both literary and practical. Poetry is often ambivalent, thus allowing for more subtlety than was prevalent in official literary culture, with its sharp black and white contrasts. This rendered the genre particularly meaningful for the educated youth disillusioned with their lives and with the official rhetoric and literature of 
the Cultural Revolution. Moreover, the brevity of the genre meant they could easily be copied into a notebook, or even memorized. This meant that Cultural Revolutionary youth could easily carry poems with them. Poetry thus allowed for literary mobility.

For some (like Shu Ting), the necessity of copying out poems represents a first step toward creating literary or poetic texts themselves. This is by no means a process confined to the "literary elite"; not only Shu Ting and other (later) obscure poets, but countless other youths copied poetry and then turned to writing their own poems. From the perspective of literary practice, I argue, the (alleged) literary quality of the poems matters less than the sheer unleashing of literary and intellectual creativity, a point I will discuss further below (see the section "Writing and copying as reading?").

Lu Xun: One of the authors mentioned most frequently is $\mathrm{Lu}$ Xun. As is widely discussed, in defining Lu Xun and his works as models for literature and art in his "Yan'an Talks", Mao Zedong firmly integrated Lu Xun into the literary dogma of the PRC. While most other May Fourth authors sank into oblivion during the Cultural Revolution, or worse, were considered counterrevolutionary, Lu Xun continued to be cherished and even worshipped, employed rhetorically for various purposes by various political factions (Goldman 1985). During the Cultural Revolution, Renmin Ribao printed contributions about Lu Xun, and his works were published both openly (including, for example, an adaptation of $\mathrm{Lu}$ Xun's “The New Year's Sacrifice" 祝福 as a lianbuanhua comic book, published in 1974 by Beijing renmin meishu chubanshe 北京人民美术出 版社) and as internal publications. The index of internal publications in the PRC lists 51 publications of works by or about $\mathrm{Lu}$ Xun during the Cultural Revolution years. Of these, the majority (45) are publications of Lu Xun's writings, sometimes edited, while only six are publications about Lu Xun and his literature. The majority of the texts are essays and letters, published in collections, some of which were published multiple times.

Of the publications about $\mathrm{Lu}$ Xun and his works, one provides readers with explanations of Lu Xun's collection of prose poems Wild Grass (野 草, 1973, first published in 1927), one provides readers with questions and answers on Lu Xun's works and a third is on Lu Xun's deliberations on translation. Among the nonfictional texts, four books contain a reference to Confucius, and three are explicitly linked to the campaign 


\begin{tabular}{|l|l|l|l|l|l|l|l|l|l|}
\hline Year & 1968 & 1969 & 1970 & 1971 & 1972 & 1973 & 1974 & 1975 & 1976 \\
\hline Publications & $1+0$ & 0 & 0 & $4+0$ & $22+0$ & $10+3$ & $4+2$ & $0+1$ & $8+1$ \\
\hline
\end{tabular}

Fig. 5.4 Temporal distribution of internal publication of works by and about Lu Xun

The first number refers to texts by Lu Xun, the second to texts about him or his works. The search for this overview was done on an OCR copy of the index to internal publications (Zhongguo Banben Tushuguan 1988); works published in or after October 1976 are not included

against Confucius. Among the published fictional texts, "The True Story of AQ” (阿Q正传, 1921) is listed twice (both published in 1972) and Call to Arms (呐喊, 1922, in which the former story was published) was published in 1976. (A list of the titles recorded in the index is provided as an appendix to this chapter in Fig. 5.6.)

Figure 5.4 maps the temporal distribution of these publications.

This pattern first follows the overall publication patterns of internal publications, with a veritable hiatus during the late 1960s (see Volland 2017b: 206). The only title published during these years is Quotations by Lu Xun (鲁迅语录), a genre clearly tied to the “Little Red Book", the Quotations by Chairman Mao (毛主席语录), first published in 1964 and heavily propagated during the Cultural Revolution (see Leese 2013: 108127; 2014; Cook 2014). This Quotations by Lu Xun was also neither the first nor the last. From 1966 onwards, the publication of Quotations by Lu Xun was officially endorsed, and earlier publications of such collections also existed (see below), suggesting that the quotations collection as a genre in itself was deeply embedded in Chinese reading and publication practices. The bulk of Lu Xun publications appeared in 1972 and 1973, with texts about him and his works only starting to be published in 1973 . This timeline runs parallel to the appearance of Lu Xun in the headlines of Renmin Ribao articles of the time (see Mühlbach 2016: 4). Thus, Lu Xun's legacy survived into the Cultural Revolution and was exploited as he was discursively reframed: Lu Xun no longer appeared as a liberalminded May Fourth author. " $[\mathrm{H}]$ is role as an author and intellectual took to the back stage and instead, his revolutionary and military-artist qualities were stressed" (Mühlbach 2016: 16). Reading habits attest to the success of this propagandistic endeavor, yet only partially. His reframing as a revolutionary made works of Lu Xun available, but readers would not 
fully subscribe to this framing of the author and many read his texts in a different way.

The reasons for the frequent mentions of Lu Xun in the autobiographies are manifold: he had been prominent during his lifetime and ever since his death; during the Maoist years, he was reframed propagandistically; and he continued to be popular after the Cultural Revolution when the autobiographies were written. The sources demonstrate that many considered $\mathrm{Lu}$ Xun and his texts to be important, and that the status of Lu Xun was high, yet ambivalent. For individuals, this importance and $\mathrm{Lu}$ Xun's overall high status can be seen from the sheer number of references in the sources and from the variety of texts referred to. However, there was also significant insecurity about how to treat him and his texts. While the revolutionary Lu Xun was venerated by official discourse, his texts were also the focus of house raids, to the dismay of Han Shaogong, who relates that when his home was plundered, all of his collections were confiscated by the Red Guards, including the works of Lu Xun (Han Shaogong 2009: 569). Others refer to texts by Lu Xun and discuss them to some extent, as summarized in Fig. 5.5. At first glance, the numbers in this chart appear to be at odds with the number of titles recorded in

\begin{tabular}{|l|l|l|l|}
\hline Title in Chinese & Title in English & $\begin{array}{l}\text { Genre (first } \\
\text { publication) }\end{array}$ & Mentioned by \\
\hline 无声的中国 & “Silent China” & $\begin{array}{l}\text { essay (written 1927- } \\
\text { 1929, first published } \\
\text { 1932) }\end{array}$ & Gao Hua 2006: 134 \\
\hline 野草 & Wild Grass & $\begin{array}{l}\text { collection of prose } \\
\text { poems (1927) }\end{array}$ & Wu Hong 2012: 121 \\
\hline 两地书 & Letters between Two & $\begin{array}{l}\text { love letters between Lu und Xu Guangping, } \\
\text { edited by Lu Xun (1933) }\end{array}$ & $\begin{array}{l}\text { Huang Xiaolong 2010; } \\
\text { Qi Zhi 2011 }\end{array}$ \\
\hline $\begin{array}{l}\text { "一要生存, 二要温 } \\
\text { 饱, 三要发展" }\end{array}$ & $\begin{array}{l}\text { Quotation from } \\
\text { “Letter from Beijing” }\end{array}$ & published letter (1925) & Zhang Yang 1999: 52 \\
\hline 长城 & “Great Wall” & essay (1925) & Zhang Yang 1999: 80 \\
\hline 纪念刘和珍君 & $\begin{array}{l}\text { “In Memory of Miss. } \\
\text { Liu Hezhen” }\end{array}$ & essay (1926) & Zhang Yang 1999: 419 \\
\hline $\begin{array}{l}\text { 鲁迅文集·杂文集·华 } \\
\text { 盖集 }\end{array}$ & $\begin{array}{l}\text { Collected Works by Lu } \\
\text { Xun }\end{array}$ & various & $\begin{array}{l}\text { Zhao Yuesheng 2009: } \\
\text { 284 }\end{array}$ \\
\hline 阿 Q 正传 & “The True Story of AQ” & fiction & $\begin{array}{l}\text { Wu Ningkun 1993: } \\
\text { 238 }\end{array}$ \\
\hline 鲁迅语录 & Quotations by Lu Xun & collection of quotations & Qi Zhi 2011 \\
\hline
\end{tabular}

Fig. 5.5 References to texts by Lu Xun in autobiographical sources about the Cultural Revolution 
Fig. 5.3. This relates to the fact that Fig. 5.3 presents the titles mentioned most often, while Fig. 5.5 also includes references to quotations.

Gao Hua read Lu Xun's "Silent China" in late 1966. His remarks on the text illustrate that readers would not necessarily fully accept the image of $\mathrm{Lu}$ Xun as a warrior, but instead they continued to read his texts for the resonances with their own lives. In "Silent China", first written in February 1927 and presented in Hankou at a Youth Assembly of Christian Youth, ${ }^{7}$ Lu Xun:

criticized the large-scale suppression of speech and writing during the Qing dynasty and the early Republican era for producing a "silent China"... for centuries. He had expected that the May Fourth New Culture Movement would restore regular speech to China by offering a new language more accessible to the common people, by facilitating the circulation of modern ideas, and by creating a genuine voice for a new era. But the success of the modern vernacular was not enough to transform the country into an “articulate China". (Yang Haosheng 2016: 49-50)

Lu Xun thus laments that the reforms that were begun during the May Fourth era did not bring about what they had promised. Reading the text in late 1966, Gao Hua "was surprised that what Lu Xun expressed a few decades ago still reflected reality" (Gao Hua 2006: 134). In Gao Hua's view, even the seventeen years since the establishment of the PRC had not served to give a voice to ordinary Chinese citizens.

Huang Xiaolong 黄晓龙 $\left({ }^{*} 1943\right)$ relates an episode of desperation in the face of his Cultural Revolution experiences. The only way out, it seems to him, is death, a realization that relieves him. Suddenly, however, he recalls Letters between Two, the heavily edited correspondence between $\mathrm{Lu}$ Xun and his wife Xu Guangping mentioned in the preceding chapter (McDougall 2000, 2002). A story that Lu Xun tells his wife makes him change his mind.

It roughly went like this: should I encounter a tiger that wants to eat me, I'll climb a big tree, and as long as the tiger waits down there, I'll wait up in the tree and under no circumstances will [I] come down. In case I should die from hunger, I'll first firmly tie myself to the tree with a leather belt. [In that way] even if I should die, I will under no circumstances let myself fall down and let the tiger fulfil his desire. (Huang 2010) 
For Huang, therefore, Lu Xun's determination becomes the inspiration to not give in to the enemy and instead to persist. He thereby relates $\mathrm{Lu}$ Xun's words that he has stored in his memory to the reality of his life in the Cultural Revolution.

Qi Zhi 启之 (“The Enligthener," pen name of the film scholar Wu Di 吴迪 *1953) also refers to Letters between Two. He even abandoned his “Great Linkup" (da chuanlian 大夰联 ${ }^{8}$ ) in order to immerse himself in the works of Lu Xun, even though he found them difficult to understand.

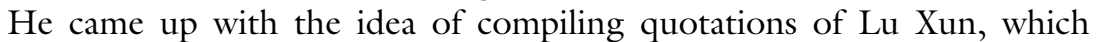
caused some turmoil among his family. He picked up some white paper, bound it together as a book and wrote Quotations by Lu Xun on its cover. When his activist elder sister, returning home from her Great Linkup, discovered what he was doing, she was appalled: "Only Chairman Mao can have Quotations" (Qi Zhi 2011). His parents likewise urged him to stop. After all, their house had just been raided by the Red Guards. Unable to stop, however, Qi Zhi continued writing down quotations, but making sure he hid them in secret places, until:

I made an extremely painful discovery - on the small bookshelf in the outer room, there was a Quotations by Lu Xun published in 1950. Edited by Song Yunbin, in vertical typesetting, two volumes. Shanghai Lianyi Publishing House. Comparing [them] carefully, [I realized that] many of the quotations I had compiled were in these [published volumes]. This was a heavy blow to my activism, and [from then on] I did not hide all my copied volumes any longer. 30 years later, I mentioned the incident to my eldest sister who unexpectedly asked me: "Really? That was happening?" (Qi Zhi 2011)

Youth activists like Qi Zhi's sister and the Red Guards who confiscated Lu Xun's work from Han Shaogong's house were striving to become true heirs to the revolution. For many, the Cultural Revolution was about performing the revolution and thus proving themselves worthy heirs to the first generation of the communist revolution in China (on this, see Yang Guobin 2016). Claiming it to be unrevolutionary to compile quotations by Lu Xun (even though publications of the same title had existed before the Cultural Revolution and were officially endorsed as of 1966) and confiscating the works of Lu Xun can be seen in this light. However, this also attests to the ambivalence of his status and, of course, to the 
overall sense of confusion caused by the lack of media reports, revolutionary zealousness and sheer fear. After his realization that published collections of Lu Xun quotations already existed, Qi Zhi turned to other authors (Li Dazhao, Guo Moruo, Gorky, Shakespeare, Tolstoy, Hugo and Rolland), and considered himself quite scholarly. However, according to his account, Lu Xun left the deepest impression on him.

For Huang Xiaolong, the love letters presented inspiration during a dark period of his life; for Qi Zhi, Lu Xun's writings represented literary and intellectual inspiration; for both, the books were not just a source of inspiration, one deciding life and death (Huang) and the other his main source of inspiration (Qi Zhi). This may have to do with the high quality of the texts by Lu Xun, but also with his status during the Cultural Revolution when he was transformed into a revolutionary author by official propaganda.

Lu Xun is remembered by many as meaningful childhood reading that continued to matter to the literary practices of members of the educated youth generation. Zhang Yang, the author of The Second Handshake, for example, writes "since my childhood, I loved and worshipped Lu Xun" (Zhang Yang 1999: 52; see also ibid.: 57). A quotation by Lu Xun seemingly had lasting impact on him: he recalls a notebook of his uncle's that had a saying by a famous person printed on each page, such as a quotation by Darwin ("Broad desire for knowledge often can turn a person into a systematic erudite scholar.” 广泛的求知欲, 往往可以使人成为有系统的 博学家。) and Lu Xun's “You first need survival, second you need clothes and food, and [only] third you need development" (一要生存, 二要温饱, 三要发展, Zhang Yang 1999: 52) from “Letter from Beijing” (北京通 讯 1925), suggesting the long-lasting impact of such childhood readings that stayed with Zhang until later in life. He also recalls having read "In Memory of Miss Liu Hezhen” 纪念刘和珍君 (written on April 1, 1926) as a child and even includes a quotation that he claims to remember from that time (Zhang Yang 1999: 419). Lu Xun remained perhaps the most important literary reference for Zhang. During the 1960s, Zhang read Lu Xun's brief essay “Great Wall” (长城) and was moved by Lu Xun's ability to "summarize" 2000 years of Chinese history (Zhang Yang 1999: 80). In 1967, similar to Qi Zhi, he also compiled (bianzuan 编暮) his own Quotations by Lu Xun (鲁迅语录), not for publication, but for friends (Zhang Yang 1999: 21). Zhang points to Lu Xun as his most important literary inspiration (Zhang Yang 1999: 79) and describes how he devised a pen name for himself modeled after Lu Xun (Zhang Yang 1999: 59). Lu 
Xun's writings thereby served as a source of inspiration for Zhang Yang as he himself became an author.

The example of Wu Hong 巫鸿 ( * 1945), now a professor of art history at the University of Chicago, demonstrates the connections between reading, the scarcity of reading materials, memory and the practices of writing in a different way. Wu notes that whatever text he found interesting he would read multiple times in order to memorize it, even if it were a novel or autobiography (Wu 2012: 118).

One thing is interesting: maybe because at the time [my] brain basically was empty (political propaganda never encouraged independent thinking), and [my] spirit often was in a state of extreme concentration and nervousness, memorizing books became something rather easy [for me]... This ability later helped me get through a difficult time. (ibid.: 120-121)

Later, he is imprisoned and in an otherwise empty cell he finds a copy of $\mathrm{Lu}$ Xun's collection of prose poems Wild Grass. The existence of Explanations of Lu Xun's “Wild Grass” (鲁迅《野草》注解), published internally in 1973 (Zhongguo Banben Tushuguan 1988: 336), attests to a certain ambiguity attributed to the text. The copy Wu Hong finds carries the name Liu Xun (刘迅), based on which Wu guesses that the earlier occupant of the cell was from the elder generation and from artistic circles. Within one day, according to his account, he memorizes all the poems in the collection and he carries this memory with him as he is subsequently transferred to another, even more horrifying prison. "There, I wrote down anew Lu Xun's poems from memory. This was later discovered by the prison guard but not confiscated" (Wu 2012: 121). These statements all suggest the literary importance attributed to Lu Xun, the ubiquity of handwritten copies and notebooks and the wide diffusion of handcopying (see also the next section of this chapter). The educated youth wrote in their notebooks whatever they considered worthy of attention. Zhang Yang's compilation of his Quotations by Lu Xun indeed suggests a writing project with a clear aim as to the contents and audience of his notebook. The "Liu Xun" notebook, however, suggests another dimension of Cultural Revolution hand-copying practices: their large scale. A previous prison inmate had written down a complete version of Lu Xun's Wild Grass, and Wu Hong, in turn, indicates that he memorized and wrote down the entire collection again. Memory thus plays a significant 
role in the preservation and circulation of handwritten texts. These anecdotes also attest to the intellectual efforts individuals undertook during the Cultural Revolution to satisfy their own and their peers' thirst for reading materials. (Even though, in the absence of material evidence, it is impossible to verify how accurate both the Liu Xun transcription and Wu Hong's transcription were as compared to an authoritative edition by $\mathrm{Lu}$ Xun.)

In the accounts referred to here, Lu Xun appears as an important source of inspiration, attesting to the overall high status of the author during the long 1970s. However, only in the retelling of the tiger anecdote by Huang does Lu Xun appears as the brave revolutionary. In the others, the emphasis is on $\mathrm{Lu}$ Xun the author of texts that provide readers with inspiration or important insights into their own reality. It is also important to note that the majority of texts referred to are essays. Their relative popularity during the era, I would assume, may be related to (at least) three factors. First, this was an influential genre before the Cultural Revolution, and essay-reading was thus a familiar practice for many. Second, as the genre discusses concrete questions pertaining to real life, essays of earlier times, such as those by Lu Xun, could be interpreted with an eye to contemporaneous, Cultural Revolutionary experiences. Third, the relative brevity of these texts turned essays into appropriate intellectual consumer goods for Cultural Revolutionary reading: they could be finished in a short time; their main arguments could be easily memorized; and excerpts could be meaningfully copied into a notebook. Similar to poetry, essays could thus be carried, either on paper or in the memory, turning the Cultural Revolution not only into an era of poetry, but also into the era of the essay. (It should also be noted that Lu Xun was an avid author of essays.)

Romain Rolland: The French novelist Romain Rolland (1866-1944) and his writings are cited as meaningful by a number of the educated youth. Rolland's multivolume novel Jean-Christophe was written from 1904 to 1912 and received broad international attention and acclaim. In China it came under attack in 1960 (Volland 2017b: 203). The novel on the one hand is an example of a classic bildungsroman; on the other hand, it was influenced by Russian novelistic practices, most notably by Tolstoy. The fictional Jean-Christophe is a musician of German origin modeled after Beethoven, and the novel traces the life of its main character, including his loves, his friendship with the poet Olivier and their involvement in the Parisian workers' movement. 
The novel was read by many during the Cultural Revolution. When the historian Gao Hua had to relocate with his family at the time, much to his pleasure, he found that their new home was in the immediate vicinity of the library stacks of a middle school, and so he started reading many Chinese and foreign books, especially Russian and Soviet literature, but also Jean-Christophe. In a similar vein, Ma Bo 马波 (*1947), son of Yang Mo, the author of the successful pre-Cultural Revolution novel Song of Youth, was repeatedly criticized and sent into the mountains during his rustication; here, living and working conditions were the hardest, not least because of the solitude. Ma Bo describes how he found solace in books:

This time it was true solitude. My only companions during those long, lonely nights were characters from books. Whenever I felt empty and frightened, whenever my courage deserted me, I tried to imagine myself in their midst. Too bad it didn't do much good. I even turned to Romain Rolland's Life of Beethoven for inspiration, copying memorized passages into my notebook. (Ma 1995: 280)

Reading provides him with comfort, similar to Shu Ting quoted above, who declares "only books could soothe me" (Shu Ting 1999 [1980]: 300). A number of authors point to the importance of Rolland's multivolume novel Jean-Christophe, which was a favorite among young people in the years before the Cultural Revolution (Wu 2012: 118-119); many note that they were fascinated by its egocentric main character (Ye and Ma 2005: 94). In her description of the books she read, Xu Xiao, who would be sent to prison together with Zhao Yifan in 1975 and would soon after participate in the activities of the underground journal Today, notes that Jean-Christophe left her in a state of ecstasy, and the story of Olivier and his sister Antoinette moved her to tears (Xu Xiao 1999a: 159). She then remembers that the novel was among the first foreign novels to be published after the Cultural Revolution and that she of course bought a copy, but never in fact read it again for fear of destroying her memory of the text.

Wu Hong also describes the influence of the book on him, having read it shortly before the Cultural Revolution:

I felt bitter about ideological control at the university, but at the same time found no way out in reality. The abstract characters in the book became beings much truer to life than real crowds. Together with Christophe, 
some idealized historical heroes like Beethoven and Michelangelo, became my intimate friends (miyou 密友) and bosom friends (zhiyin 知音), their powerful spiritual strength moved me to the degree of seething with excitement and having no control over myself. (Wu 2012: 119)

Jean-Christophe (and similar readings) satisfied the readers' curiosity about life outside China, their interest in worlds beyond their own. Moreover, I argue, they fed into the heroism of the age. As explained in the introduction to this book, in propaganda as well as in official literature and art, heroic figures had become the main point of reference. However, with characters such as Jean-Christophe, the master narrative of what a hero should be like was being rewritten. According to the official dogma, the hero subordinated all his actions to the right cause, i.e., the struggle for a bright future under communism. He (or she, as there were a few female heroes) demonstrated (almost) superhuman physical strength, and political integrity, but no individual desire, be this the desire for clothes, food and drink beyond the most simple and urgent fare (and many heroes would even go without, thus demonstrating their self-control), or to the need satisfy emotional or sexual desire (personal happiness was postponed until the achievement of communism, see Huang 1973; Henningsen 2014). With Jean-Christophe, there emerges an alternative hero, one that offered himself to Chinese 1970s readers for identification. The influence of Russian novelistic practice and the protagonist's engagement with the French workers' movement rendered Jean-Christophe compatible with earlier reading experiences. However, the fact that he is an artist, one modeled after Beethoven, introduces a distinctly different element: the individual as exemplified by one of the geniuses of late eighteenth- and early nineteenth-century European high culture. Such a protagonist thus not only stands for extraordinary artistic achievement, but also his bourgeois culture and the fulfillment of personal ambitions and desires and the promise of individualism. Both Jean-Christophe and the example of Salinger and Kerouac discussed below thus represent different modes of writing heroism. These works can be related to later literary developments that are commonly associated with the early post-Cultural Revolution years. These reading practices and their long-term impact, therefore, attest to the roots of these post-Maoist developments in the literary and intellectual practices of the Cultural Revolution years.

Jack Kerouac and Jerome D. Salinger: Contemporary western literature also became important reading for many educated youth, including $O n$ 
the Road (internal publication in China in 1962; originally written on a handscroll 1949-1951 and published in the US in 1957) by Jack Kerouac (1922-1969) and The Catcher in the Rye (internal publication in China in 1963; first published in the US in 1951) by J. D. Salinger (1919-2010). Both novels are angry reflections on contemporary society, written from the perspective of disenchanted, alienated and predominantly male angry youth looking for their place in society, their path into life. The British play Look Back in Anger (internal publication in China in 1962; world premiere in London 1956) by John Osborne and the equally popular book Ticket to the Stars (internal publication in 1963, original publication in the SU in 1961) by the Soviet author Vasily Aksyonov (1932-2009) could be added to these two American titles as they debate similar topics. These titles were made available in Chinese in the early 1960s within the internal publication system. Theoretically, these translations were thus produced for a narrowly defined circle of readers (Song 1997, 2007; Kong 2002; Shen 2007; Jiang and Liu 2013) in what amounted to a "restricted public sphere" (Volland 2017b: 192-201): Access depended on one's rank within party hierarchy, and the purpose of reading these texts was to teach these party readers about intellectual and literary developments inside and outside of China. However, the books found readers beyond these narrowly defined party circles, particularly the texts written by the Beat Generation authors (only On the Road is Beat Generation literature in a strict sense, yet in particular The Catcher in the Rye seems to have been perceived along similar lines in China as both are connected to notions of a generation of youth struggling to find their place in society). Wu Hong suspects that he and his fellows were most likely the first unofficial readers of titles like these, even before the Cultural Revolution (Wu 2012: 119), receiving them through private channels that endowed their reading with underground qualities. In the following years, Beat literature became increasingly relevant to the generation who found some of their experiences mirrored in the texts of the Beat authors. The painter Peng Gang 彭刚 (*1952) and the author Mang Ke were even inspired to reenact $\mathrm{On}$ the Road when they left Beijing in search of adventure and an act of (self-)liberation (Liao and Chen 1999a: 184) "imitating this both romantic and insane mode of the American author Mauriac's [sic] On the Road" (Gan 1999: 273).

While Gan Tiesheng 甘铁生 (*1946) erroneously names the French novelist and Nobel Laureate François Mauriac (1885-1970) instead of Jack Kerouac, another author who emphasizes the importance of the text 
for his generation provides his readers with the wrong English title of the novel: On the Way. Similarly, Duo Duo 多多 (*1951, pen name of Li Shizheng 栗世征) points out that the play Les Chaises was important to his generation, wrongly attributing authorship of the play to Beckett, rather than Ionesco (Duo Duo 1999: 195). Such factual errors do not undermine the importance of the respective texts. They do, however, point to the unofficial circulation of the texts and knowledge at the time, to the transmission of knowledge in informal circles, as well as to the fragmentariness of sources and, possibly, the distortion of memory over time. Many of these autobiographical essays were written, and the interviews were conducted, roughly two decades after the events described. The continuing influence of these texts is also attested by other authors, who indicate that $O n$ the Road provided them with meaningful inspiration, including Bei Dao, Xu Xing 徐星 ( $\left.{ }^{*} 1956\right)$, Wang Shuo 王朔 (*1958), Wei Hui 卫惠 (*1973) and Mian Mian 棉棉 (*1970, see Cai 2010).

Autobiographical accounts attest to the fact that ample reading materials were available during the Cultural Revolution and that these readings were very important, albeit having different meanings for different readers. Access to these readings, however, was limited and depended heavily on connections, be this within the family or among trusted friends, as well as on the person's audacity. After all, at the time these titles were not considered acceptable reading materials for the wider reading public by the regime, and they were deemed counterrevolutionary. Reading such censored materials could be dangerous to the reader and their family's security.

\section{WRITING AND COPYING AS READING? Hand-Copying Practices}

The particular context of reading during the long 1970s, particularly the political turmoil, the streamlining of the official book publication system and the rustication movement, all had an influence on the nature of reading materials and, as a consequence, on practices of reading. Books were scarce, and easily torn apart as they were carried to the countryside or shared among friends. Many educated youth therefore turned to hand-copying (shouchao 手抄) texts: memorable quotations were written into notebooks (and often memorized), and sometimes entire volumes were copied down. While these practices were not new for China, their 
sheer number is astonishing. Also, these practices dominated the scene much more than during other, less turbulent times.

Copying and writing down texts, or parts thereof, also need to be considered as a reading practice. The writing down of extant text preserved these texts, made them available to other readers and enabled the texts to travel further. The mobility of handwritten entertainment fiction and the particular mechanisms of their copying stimulated literary creativity. The autobiographical sources can therefore be meaningfully consulted in relation to these particular reading practices and they provide numerous examples, for example, in the texts by Wu Hong and Shu Ting discussed earlier in this chapter. Several authors relate that they handcopied into their notebooks from other texts. This pertains in particular to poems, or books, particularly internal publications. In the excerpt by Shu Ting quoted above, she notes that copying poems served as a sort of exercise for her, and notably she would later become an influential obscure poet. From her hand-copying activities, we can see that Pushkin, Tagore, Byron, Mickiewicz, Keats, Yin Fu, Zhu Ziqing, Ying Xiuren and He Qifang were important to her (Shu Ting 1999 [1980]: 300-301).

$\mathrm{Xu}$ Xiao describes her first encounter with hand-copied texts in her autobiographical account. In 1973, when she was working as a primary teacher, she received a collection of poems from a friend. Had this been an ordinary printed book, she would not have paid it much attention. However, the particular materiality of the book (a hardcover notebook with lined paper that was available at the time for six jiao and was filled with pretty handwriting) aroused her curiosity; she read the collection "in one single breath" (Xu Xiao 1999b: 380). She still remembers the first of the poems, “The Golden Trumpet” (金色的小号), and another six-line poem “Smile, Snowflakes, Stars” (微笑.雪花. 星星), which she memorized instantly (ibid.), both poems by Bei Dao, as she would find out years later. Yet it was not only the materiality of the pieces that left a deep impression on her. Given that her poetic experiences had stopped with texts such as He Jingzhi’s 贺敬之 ( *1924) “Song of Lei Feng” (雷锋之歌, 1963) and “Sanmenxia - Dressing Table” (三门峡——梳妆台, $1958^{9}$ ), which she had learned before the Cultural Revolution in recitation classes in the cultural palace (ibid.: 381), it is unsurprising that "these completely new verses inside the shouchaoben could not but infect a solitary and inexperienced 18-year-old girl" (Xu Xiao 1999b: 380). Xu Xiao further relates that she received several hand-copied poems and internal publications, 
such as $A$ Ticket to the Stars, A Catcher in the Rye and The New Class (Xu Xiao 1999b: 381).

Poems written during the Cultural Revolution were often hand-copied and then circulated-Xu Xiao gave her poems to Bei Dao for feedback (and stopped writing poetry when she received no encouragement from him; Xu Xiao 1999b [1997]: 381). Lin Mang 林莽 ( $\left.{ }^{*} 1949\right)$ likewise started writing from these practices. He recalls that he first came into contact with the poems of Guo Lusheng through a copy of his texts by Jiang He 江河. As Jiang had copied the first half of Guo's "Believe in the Future” (相信未来, 1968), claiming that was enough, Lin Mang likewise only copied this first half. He also copied two poems by Bei Dao (“Smoke” 烟 and "Liquor" 酒) from Jiang, while copying Guo Lusheng's “Ocean Trilogy” (海洋三部曲) from Song Haiquan (宋海泉, “1949). "Because of the enlightenment of such poems, and especially after reading modernism such as in the works of Baudelaire the orientation of [my] writing began to change" (Liao and Chen 1999b: 291).

The demarcations between reading and writing were fluid. Poetry practitioners would copy poems by others and then write down their own poetry and circulate it among friends and like-minded others. The act of copying preserved extant poems and helped in their circulation. As with shouchaoben fiction, however, shouchao practices also provided creative strategies and strategies of interpretation, in the course of which literary pieces were modified, as in the case of Jiang He considering the first half of the poem to be sufficient. Yet shouchao practices not only influenced the form, content and appearance of the works transmitted; they could also significantly interfere with the lives of their authors. Genzi (one of the three core members of the baiyangdian group, the other two being Duo Duo, and Mang Ke) experienced trouble after his poems were found to be circulating widely. The matter was only dropped after a literary research institute (中国文学研究所) investigated his poems and declared that they were not very harmful. For political reasons, their literary salon stopped, yet "the range in which the poems were copied and circulated expanded even more" (Duo Duo 1999: 199).

These narratives emphasize the importance of writing for the educated youth. Even if they were not writing new texts themselves, they would write poems into their notebooks, along with quotations, excerpts from texts they had read and, in some cases, entire books that they found meaningful and important. These notebooks were sometimes circulated among friends, and in their letters the educated youth discussed their readings. 
Reading and writing were thus clearly intertwined. Many also attempted writing poetry. Ma Jia (马佳 *1953), for example, relates that he wrote numerous poems. As none of these was ultimately published, he "made no contribution to the Chinese movement for new poetry" (Liao and Chen 1999a: 221). What later became known as obscure poetry to Ma Jia was at the time clearly entertaining for a lively circle of friends: "Everyone drank, painted and discussed poetry... Strictly speaking, at the time we had all this fun already" (Liao and Chen 1999a: 221).

The emphasis that is given in these accounts to the copying (and writing) of internal materials and poetry serves to position the authors of these accounts within larger literary and intellectual trends, such as the blossoming of obscure poetry after the Cultural Revolution, $\mathrm{Ma}$ Jia's ridicule notwithstanding. This firmly positions the authors of the autobiographical accounts in relation to literary trends that have been deemed important by literary history, and at the same time it reinforces the importance attributed to the genre of poetry itself.

Storytelling is also related to hand-copying practices as this refers to further unofficial ways of circulating these pieces of otherwise invisible writing. Such circulation pertained to unofficial literature, as in the examples discussed above, but also to texts that were officially endorsed by the leadership, such as Le Comte de Monte-Cristo by Alexandre Dumas. Perry Link mentions that this book "became well known and an intensely sought prize during the Cultural Revolution, when Jiang Qing listed it with seven other works as 'highly recommended' reading" (Link 2000: 170). Zhang Langlang, for example, who was facing the death sentence in 1970, told the story of Le Comte de Monte-Cristo to the Red Guards guarding him, who in return provided him with tea and cigarettes (Zhang 2009: 121). The enduring popularity enforced from above and practiced at the grassroots level may also explain the success of the book on the post-Maoist book market. Several former educated youths have noted how they or others recounted entire books to their fellows (for example, Sha Mou 2010; Ye and Ma 2005: 121), sometimes receiving good tea or special foods as a reward. Zhang Yang relates how after his first release from prison he sat with his friends at the fireside enjoying their gossip and storytelling, including, to his surprise, "his" The Second Handshake (Zhang 1999: 31-32, see also my elaborations in Chapter 2). Wu Hong in turn notes that he was an avid storyteller. Every evening after the political studies session, he would sit on his bed and tell stories. One of the listeners would take detailed notes, and the next day Wu Hong would tell 
the same story in another room (Wu 2012: 122). While the purpose of this note-taking is not entirely clear, it affirms the link between the oral and written circulation of popular stories.

\section{Blind Spots-What Is Missing?}

As demonstrated so far, the reading materials and reading practices of the Cultural Revolution varied significantly. In this chapter, I have elaborated on the diversity of the texts available, on the importance attributed to works that were non-canonical by the standards set at the time by the CCP, and on the connection between reading, copying and writing in 1970s hand-copying practices. Conversely, however, it is worth considering what is missing in these accounts and it is worth accounting for these blind spots. While the texts discussed in autobiographical sources were clearly read at the time and had a meaning for their readers (assuming that the narratives in the autobiographies are not outright fiction, lies, wrong or false memories), it would be wrong to assume that texts that are not mentioned were not read at all. Rather, an even greater variety of readings may be assumed, which, for various reasons, the readers decided not to include in their accounts at the time of their writing: they may have forgotten certain texts; they may have considered them not so important; or they may have simply not been in line with whatever intellectual or ideological image of themselves they want to convey.

Three elements are conspicuously absent (or at least underrepresented): first, given the large amount of foreign fiction, it is important to consider the fate of socialist realist fiction during the decade, in particular in light of the wide propagation of Soviet and Chinese fiction during the seventeen years. Second, while hand-copying practices are discussed at length, elaboration on entertainment manuscript fiction is largely missing. Third, and this may explain the first two elements, many people did not document their Cultural Revolution reading practices at all. What are the implications of this silence for the image that is conveyed of the $1970 \mathrm{~s}$ reading landscape?

Socialist realist fiction: Chinese readers of the 1970s were cosmopolitan in their reading aspirations, as is clear from the popularity of authors like Rolland, Salinger and Aksyonov. However, only a minority of authors of autobiographies refer to the canon of "socialist cosmopolitanism" (Volland 2017a) that dominated the Chinese cultural and literary field 
from 1949 to the mid-1960s. Socialist cosmopolitanism describes how Chinese translators, authors and readers searched for their place within the socialist cultural and literary universe that followed the Soviet model. Astonishingly, Chinese socialist realist fiction, such as The Sun Shines over the Sanggan River (太阳照在桑干河上 by Ding Ling 丁玲, 1948), Defend Yan'an (保卫延安 by Du Pengcheng 杜鹏程, 1954), Great Changes in a Mountain Village (山乡巨变 by Zhou Libo 周立波, 1957) and Red Crag are only mentioned in a few instances in the autobiographical sources. This also holds true for titles from the Soviet Union. While Soviet titles published within the internal publication system in general were welcome reading for many educated youths (Li 2018: 171-189), only two Soviet titles which had been published officially in China are mentioned four or more times: Ostrovsky's How the Steel was Tempered and The Story of Zoya and Shura (Kosmodemyanskaya). He Donghui (2010) points out that How the Steel was Tempered was a central piece of literature within the sphere of texts propagated for normative reading (Wagner 1995) and it continued to be propagated even after the break with the SU (see also Green 2017; He 2010; Yu 2002). Of the authors in our sample, two mention that they read the novel during their pre-Cultural Revolution childhood years. Huang Xiaolong, a third author, read the novel in 1971, but found it a disappointing experience. In fact, he dismantles the entire normative mode of reading in that he blames numerous mistakes he made in his life on following Pavel Korchagin, the novel's protagonist, who was propagated as a model for Chinese readers (Huang 2010). Fiction from the rest of the socialist cosmos, i.e., countries such as the GDR or North Korea, are entirely missing.

Socialist cosmopolitanism is therefore largely missing from the sources. Rather, the majority of titles mentioned subscribe to an earlier cosmopolitanism oriented toward European modernity. Following Pheng Cheah, I consider the "cosmopolitan optic" as meaningful, not so much as one of "perceptual experience but of the imagination. World literature is an important aspect of cosmopolitanism because it is a type of worldmaking activity that enables us to imagine a world" (Cheah 2008: 26). In their cosmopolitan imagination, these readers turn to world literature, including contemporary authors of the Beat Generation, and authors such as the Indian Nobel Laureate Tagore, who can be considered a truly global world literature author (after the Nobel Prize, his works were widely promoted in the socialist world with, for example, numerous of his texts translated for and published in the literary magazine Yiwen 译 
文). ${ }^{10}$ Of the official literature of the Cultural Revolution, a number of poets are mentioned, as are the works of Mao Zedong (albeit, as in the case of Shu Ting, making it clear that his writings are considered burdensome and not worth being memorized by at least a part of the readership). Similarly, the fiction of the Cultural Revolution (discussed in Yang 1998) is missing from the accounts.

Shouchaoben fiction: Hand-copying practices are widely discussed in the sources. There is also evidence of the wide reach of the phenomenon of shouchaoben fiction in other sources: Michel Bonnin, for example, mentions that of the people he interviewed, "[a]bout a third... had read at least one of these works, and all of them had heard of them" (Bonnin 2013: 349). Conversely, shouchaoben fiction is largely absent from the autobiographical accounts. Only one author in the sample discusses these texts at length, and this is Zhang Yang, the author of The Second Handshake. Why is this? What can be drawn from this? I argue that this illustrates the low status attributed to shouchaoben fiction after the end of the Cultural Revolution. I would suspect that many of those writing about their readings also read these entertaining stories, yet they chose not to write about them because the texts were not considered meaningful within their narratives. In a conversation with me, for example, a Shanghai-based literary scholar said that of course he also read these texts and even had a stack of them at home. However, given what he considered their low literary quality, he threw away all of them. It seems that these stories are valued as negative cultural capital because of their high entertainment value and their alleged low literary quality and they have therefore been forgotten, either consciously or unconsciously. While other readers considered these texts meaningful, both at the time and now with hindsight, this blank spot in the autobiographies points to the limitations of using life-writing texts as historical evidence, as they represent a carefully constructed image of the past. This is not to say that their authors consciously distort reality, but their accounts first and foremost serve their present and the image of the self that the authors wish to present to their readers.

Silent China: The autobiographical sources used therefore in a way reproduce the "silent China" that Lu Xun described with regard to Republican China and that Gao Hua lamented about with regard to the Cultural Revolution. Only certain types of readings are documented and written about. The majority of the autobiographical sources are written 
by former educated youth who after the Cultural Revolution joined the ranks of the intellectual, literary or artistic field (and, as mentioned above, the majority of the authors, albeit not all of them, are male). Those who stayed in the countryside, as well as those who were not educated youth, but instead workers, peasants or soldiers, had less access to varied readings at the time. After the Cultural Revolution they also had less access to publication opportunities (on this see, for example, Gao 2008; Yang Guobin 2003, 2005) and, most likely, no interest in writing and publishing the stories of their lives. Not speaking up also feeds into the discourse about the "Silent Majority" brought up in 1996 by Wang Xiaobo's seminal essay of the same title (Veg 2019: 52-83; Huang 2007: 187-188). The silence referred to in "silent China" thus documents what can be seen as twofold invisible reading, mirroring in some ways the practices of invisible writing. First, reading often had to be clandestinely at the time, and, second, as it is underrepresented (or un-represented) in accounts about the Cultural Revolution these readings are invisible once more to the eyes of later generations.

The absence of certain texts, or text types, from the autobiographical accounts thus does not mean they were not read, nor does it mean they were not meaningful. The observations related in this chapter can be considered relevant documentation of what might be termed "noisy China," i.e., the part of society with access to publication venues, and with the ability and the intention to write about their experiences. Given the size of the rusticated population, this still represents a major part of society, and one that would become particularly influential in the postMao era. Yet even this "noisy China" may have chosen to be silent about certain issues, such as reading (and perhaps even enjoying) the thrills of entertainment shouchaoben.

Thus, as much as the autobiographical texts document the reading landscape of the 1970s, they are also about the respective time in which they were written - the 1980s, 1990s, 2000s or 2010s-and about the images of their own selves that the authors want to convey (or what they believe their readers expect of them). The reading landscape(s) drawn in these autobiographical texts are also those of the educated youth (and especially that of a particular cohort, namely those with access to and the declared intention to publish their narratives of the past), excluding different landscapes that may have been meaningful to other social groups. The texts thus represent a filtered view of the reality of the 1970s, for all that these filters provide the readers of the autobiographies with meaningful interpretations of the past. 


\section{Reading Materials Beyond Autobiographical SOURCES}

Autobiographical sources about the reading practices of the long Cultural Revolution decade first of all attest to a literary and intellectual field that was not confined to the narrow realm of what the CCP may have wanted its subjects to read. Rather, a world of reading appears that was cosmopolitan and various, connecting readers of the 1970s to world literature, global intellectual debates and earlier literary practices, as well as anticipating post-Cultural Revolutionary developments. All ruptures experienced during the Cultural Revolution notwithstanding, continuity with these earlier, later and global developments existed. Reading practices of the Cultural Revolution were thus almost as varied as the successful popular post-Cultural Revolution publications and, in many cases, they anticipated these later developments. Obscure poetry had its origins in the literary salons of the Cultural Revolution and in shouchao practices; many of the translations successfully published after the Cultural Revolution had their origins in the internal publications of the preceding decades (Kong 2002); and some of the post-Cultural Revolution bestsellers were either shouchaoben fiction or works from the earlier canon of socialist realism. Second, it has been demonstrated that reading practices are particularly useful for developing an understanding of intellectual and literary developments. Reading materials may continue to circulate, albeit clandestinely, and readings may continue to have meaning for their readers and continue to be discussed over long periods of time. What mattered, however, also rested on personal interest and taste, and on the question of access (including the courage of readers to consciously look for and read titles that were potentially forbidden). Internal publications, for example, were harder to access than an old edition of Dream of the Red Chamber or Lu Xun's works.

The blind spots in the autobiographical sources call for a different set of sources to complement these findings in order to gain a more comprehensive picture of the 1970s reading landscape. I therefore suggest reading shouchaoben fiction for intertextual references and for descriptions of reading practices. This, which I will do in the following chapter, offers a different, albeit filtered, access to reading materials. In reading a piece of entertainment manuscript fiction, a reader may be reminded of his/her own earlier reading of, for example, Ostrovsky's How the Steel 
was Tempered, a text that was central within the normative reading framework of Maoist China; alternatively, he/she may get a snippet of the ideas of a thinker like, for example, Darwin, when he is quoted in The Second Handshake as saying that striving for broad knowledge can turn a person into a systematic natural historian.

\section{Notes}

1. For the influence of Russian and Soviet literature, see in particular Gamsa (2010).

2. William Shirer's work on Nazi Germany was important and eye-opening, as described in Xiao Xiao's autobiography: on reading the book, an acquaintance became aware of the parallels to his own experiences and the injustices of Cultural Revolutionary China (Xiao Xiao 1999: 12).

3. For the reception of Baudelaire in China, see Bien (2013) and Yang Yuping (2013).

4. Here, Shu Ting erroneously uses 普希金诗钞 instead of 普希金诗抄.

5. Note that Shu Ting here uses the term Shieryue gemingdang 十二月革 命党 (literally "Revolutionary Party of the Decembrists") instead of the commonly used term Shieryue dang 十二月党 (“Decembrist Party") to refer to the Decembrists. Chinese sources commonly adhere to the term revolt/uprising (qiyi 起义) instead of revolution when referring to the matter. Thanks to Lorenz Bichler for alerting me to this.

6. Franz Mehring (1846-1919) was a politician and one of the earliest biographers of Karl Marx. The biography was originally published in Leipzig in 1918 in German as: Karl Marx. Geschichte seines Lebens.

7. "Silent China" was first published in a Hong Kong newspaper and soon after on March 23, 1927 in Zhongyang Ribao 中央日报 in Hankou.

8. The "Great Linkup" or "Exchange of Experience" refers to a mobilization campaign lasting from the second half of 1966 to early 1967. Red Guards could travel the country free of cost and they followed this call in vast numbers, "imagining themselves to be reliving the Long March, realizing the revolutionary myths on which they had been reared" (MacFarquhar and Schoenhals 2006: 111).

9. For a discussion of this poem, see Seeger (2014: 207-208).

10. For Yiwen, see Iovene (2014: 51-79; Volland 2017a: 153-186).

\section{Appendix to Chapter 5}

Overview of $\mathrm{Lu}$ Xun-related titles as recorded in Zhongguo Banben Tushuguan 1988 (Fig. 5.6). 


\begin{tabular}{|c|c|c|c|c|c|c|}
\hline Genre & \multicolumn{5}{|c|}{$\begin{array}{l}\text { Titles: number of editions (if more than one, year of neibu } \\
\text { publication) }\end{array}$} & $\begin{array}{l}\text { Overall } \\
\text { count: } 56\end{array}$ \\
\hline \multicolumn{6}{|c|}{ Publications about Lu Xun and his works (as judged by title in the index) } & 8 \\
\hline $\begin{array}{l}\text { 鲁迅作品学 } \\
\text { 习参考资 } \\
\text { 料: } 1973\end{array}$ & $\begin{array}{l}\text { 鲁迅的生 } \\
\text { 平及杂文: } \\
1973\end{array}$ & $\begin{array}{l}\text { 鲁迅《野 } \\
\text { 草》注解: } \\
1973\end{array}$ & $\begin{array}{l}\text { 纪念鲁迅 } \\
\text { 先生: } 1973\end{array}$ & \multicolumn{2}{|c|}{$\begin{array}{l}\text { 北京市中学语文课本中 } \\
\text { 十五篇鲁迅作品的问题 } \\
\text { 试答: } 1974\end{array}$} & 5 \\
\hline $\begin{array}{l}\text { 鲁迅的青少 } \\
\text { 年时代: } \\
1974\end{array}$ & $\begin{array}{l}\text { 鲁迅论翻 } \\
\text { 译: } 1975\end{array}$ & $\begin{array}{l}\text { 鲁迅思想 } \\
\text { 的发展: } \\
1976\end{array}$ & & & & 3 \\
\hline \multicolumn{6}{|c|}{ Texts by Lu Xun (original or edited works) } & 48 \\
\hline $\begin{array}{l}\text { Poetry and } \\
\text { prose } \\
\text { poems }\end{array}$ & $\begin{array}{l}\text { 鲁迅诗歌 } \\
\text { 散文选: } \\
1972 \\
\end{array}$ & & & & & 1 \\
\hline \multirow[t]{2}{*}{$\begin{array}{l}\text { Letters and } \\
\text { essays } \\
\text { (collections) }\end{array}$} & $\begin{array}{l}\text { 鲁迅杂文 } \\
\text { 书信选: } 4 \\
(1971)+5 \\
(1972) \\
\end{array}$ & $\begin{array}{l}\text { 鲁迅杂文 } \\
\text { 书信选 } \\
\text { ( 续编 ): } \\
8 \text { (1972) }\end{array}$ & $\begin{array}{l}\text { 鲁迅杂文 } \\
\text { 选: } 1972\end{array}$ & $\begin{array}{l}\text { 鲁迅书简: } \\
2(1972)+1 \\
(1973)\end{array}$ & $\begin{array}{l}\text { 鲁迅杂文 } \\
\text { 选读: } 1972 \\
+1973\end{array}$ & 23 \\
\hline & $\begin{array}{l}\text { 鲁迅杂文 } \\
\text { 选 ( 注 } \\
\text { 解 ) : } 1973\end{array}$ & $\begin{array}{l}\text { 鲁迅杂文 } \\
\text { 选释: } 1973\end{array}$ & $\begin{array}{l}\text { 门外文 } \\
\text { 谈 : } 2 \\
(1973)\end{array}$ & $\begin{array}{l}\text { 鲁迅书信 } \\
\text { 选: } 1973\end{array}$ & $\begin{array}{l}\text { 鲁迅杂文 } \\
\text { 不选讲: } \\
1973+ \\
1974 \\
\end{array}$ & 7 \\
\hline \multirow[t]{2}{*}{$\begin{array}{l}\text { Other non- } \\
\text { fiction }\end{array}$} & $\begin{array}{l}\text { 在现代中 } \\
\text { 国的孔夫 } \\
\text { 子: } 1973\end{array}$ & $\begin{array}{l}\text { 鲁迅批孔 } \\
\text { 反儒文辑: } \\
1973\end{array}$ & $\begin{array}{l}\text { 鲁迅论文 } \\
\text { 学艺术遗 } \\
\text { 产: } 1974\end{array}$ & $\begin{array}{l}\text { 鲁迅批孔 } \\
\text { 作品选: } \\
1974\end{array}$ & $\begin{array}{l}\text { 鲁迅论文 } \\
\text { 学艺术: } \\
1974\end{array}$ & 5 \\
\hline & $\begin{array}{l}\text { 鲁迅批孔 } \\
\text { 反儒的斗 } \\
\text { 争: } 1976\end{array}$ & & & & & 1 \\
\hline Fiction & $\begin{array}{l}\text { 鲁迅小说 } \\
\text { 选: } 1972\end{array}$ & $\begin{array}{l}\text { 阿 Q 正传: } \\
2 \text { (1972) }\end{array}$ & 呐喊: 1976 & & & 4 \\
\hline Quotations & $\begin{array}{l}\text { 鲁迅语录: } \\
1968\end{array}$ & & & & & 1 \\
\hline $\begin{array}{l}\text { Genre } \\
\text { unclear }\end{array}$ & $\begin{array}{l}\text { 鲁迅文选: } \\
1976,1976\end{array}$ & $\begin{array}{l}\text { 鲁迅著作 } \\
\text { 选 }(-) \text { : } \\
1976\end{array}$ & $\begin{array}{l}\text { 鲁迅著作 } \\
\text { 选 (二 ): } \\
1976\end{array}$ & $\begin{array}{l}\text { 鲁迅著作 } \\
\text { 选 ( 三 ): } \\
1976\end{array}$ & $\begin{array}{l}\text { 鲁迅著作 } \\
\text { 选 ( 四 ) : } \\
1976\end{array}$ & 6 \\
\hline
\end{tabular}

Fig. 5.6 Titles of internal publications of works by/about Lu Xun during the Cultural Revolution (Source Zhongguo Banben Tushugua 1988) 


\section{REFERENCES}

\section{Printed ANd Online Sources}

Bien, Gloria. 2013. Baudelaire in China: A Study in Literary Reception. Newark: University of Delaware Press.

Bonnin, Michel. 2013. The Lost Generation: The Rustication of China's Educated Youth (1968-1980), trans. Krystyna Horko. Hong Kong: The Chinese University Press; The Chinese University of Hong Kong.

Cai, Rui 蔡芯. 2010. The "Beat Generation" and the Influence of On the Road in China “垮掉的一代”及《在路上》在中国影响. Wenxuejie 12: 23-24.

Cheah, Pheng. 2008. What Is a World? On World Literature as World-Making Activity. Daedalus 137 (3): 26-38.

Cook, Alexander C. 2014. Introduction: The Spiritual Atom Bomb and Its Global Fallout. In Mao's Little Red Book: A Global History, ed. Alexander C. Cook, 1-22. Cambridge: Cambridge University Press.

Damrosch, David. 2003. World Literature, National Contexts. Modern Philology 100 (4): 512-531.

Denton, Kirk A. 2016. Literature and Politics: Mao Zedong's "Yan'an Talks" and Party Rectification. In The Columbia Companion to Modern Chinese Literature, ed. Kirk A. Denton, 224-230. New York: Columbia University Press.

Duo, Duo 多多. 1999. The Buried Chinese Poets (1972-1978) 被埋葬的中国 诗人 (1972-1978). In Sinking Holy Place: Death Pictures of Underground Poetry in China's 1970s 沉沦的圣殿: 中国20世纪70年代地下诗歌遗照, ed. Liao Yiwu 廖亦武, 195-202. Urumqi: Xinjiang qingshaonian chubanshe.

Gamsa, Mark. 2010. The Reading of Russian Literature in China: A Moral Example and Manual of Practice. New York: Palgrave Macmillan.

Gan, Tiesheng 甘铁生. 1999. Baiyangdian at Springtime 春李白洋淀. In Sinking Holy Place: Death Pictures of Underground Poetry in China's 1970s 沉沦 的圣殿: 中国20世纪70年代地下诗歌遗照, ed. Liao Yiwu 廖亦武, 268-274. Urumqi: Xinjiang qingshaonian chubanshe.

Gao, Hua , 高, and 华. 2006. Walking on the Stream of History 行走在历史的 河流. Shehui Kexue Luntan 5: 132-139.

Gao, Mobo. 2008. The Battle for China's Past: Mao and the Cultural Revolution. London: Pluto Press.

Goldman, Merle. 1985. The Political Use of Lu Xun in the Cultural Revolution and After. In Lu Xun and his legacy, ed. Leo Ou-fan Lee, 180-196. Los Angeles: University of California Press.

Green, Frederik H. 2017. The Cultural Indigenization of a Soviet "Red Classic" Hero: Pavel Korchagin's Journey through Time and Space. In The Making and Remaking of China's "Red Classics," ed. Rosemary Roberts and $\mathrm{Li} \mathrm{Li}$, 136-155. Hong Kong: Hong Kong University Press. 
Han, Shaogong 韩少功. 2009. Endless Holidays 漫长的假期. In The Seventies 七十年代, ed. Bei Dao 北岛 and Li Tuo 李陀, 563-585. Beijing: Sanlian shudian.

He, Donghui. 2010. Coming of Age in the Brave New World: The Changing Reception of How the Steel Was Tempered in the People's Republic of China. In China Learns from the Soviet Union, 1949-Present, ed. Thomas P. Bernstein and Hua-yi Li, 393-420. Lanham: Lexington Books.

Henningsen, Lena. 2014. Tastes of Revolution, Change and Love: Codes of Consumption in Fiction from New China. Frontiers of Literary Studies in China 8 (4): 575-597.

Henningsen, Lena, and Duncan Paterson. 2020. ReadAct: Reading Act Database. https://doi.org/10.5281/zenodo.3755105.

Huang, Joe C. 1973. Heroes and Villains in Communist China: The Contemporary Chinese Novel as a Reflection of Life. London: C. Hurst.

Huang, Xiaolong 黄晓龙. 2010. I Almost Killed Someone That Year 那年我差点 杀人. Rememberance 记忆 48. http://www.xujuneberlein.com/rem48.html. Accessed 15 Dec 2016.

Huang, Yibing. 2007. Contemporary Chinese Literature: From the Cultural Revolution to the Future. New York: Palgrave Macmillan.

Iovene, Paola. 2014. Tales of Futures Past: Anticipation and the Ends of Literature in Contemporary China. Stanford: Stanford University Press.

Jiang Huajie 蒋华杰, and Liu Yang 刘阳. 2013. The Evolution and Influence of the PRC's Internal Circulation System in the Context of the Cold War 冷战背 景下新中国内部发行制度的演变与影响. Zhonggongdangshi Yanjiu 5: 35-44.

King, Richard. 2013. Milestones on a Golden Road: Writing for Socialism, 194580. Vancouver: UBC Press.

Kong, Shuyu. 2002. For Reference Only: Restricted Publication and Distribution of Foreign Literature during the Cultural Revolution. Yishu: Journal of Contemporary Chinese Art 2: 76-85.

Leese, Daniel. 2013 (2011). Mao Cult: Rhetoric and Ritual in China's Cultural Revolution. Cambridge: Cambridge University Press.

Leese, Daniel. 2014. A Single Spark: Origins and Spread of the Little Red Book in China. In Mao's Little Red Book: A Global History, ed. Alexander C. Cook, 23-42. Cambridge: Cambridge University Press.

Li, Yan. 2018. China's Soviet Dream: Propaganda, Culture, and Popular Imagination. London: Routledge.

Liao, Yiwu 廖亦武, and Chen Yong 陈勇. 1999a. A Transcript of the Interview with Peng Gang and Mang Ke 彭刚、芒克访谈录. In Sinking Holy Place: Death Pictures of Underground Poetry in China's 1970s 沉沦的圣殿: 中国20 世纪70年代地下诗歌遗照, ed. Liao Yiwu 廖亦武, 183-194. Urumqi: Xinjiang qingshaonian chubanshe.

Liao, Yiwu 廖亦武, and Chen Yong 陈勇. 1999b. Transcript of the Interview with Ma Jia 马佳访谈录. In Sinking Holy Place: Death Pictures of Underground 
Poetry in China's 1970s 沉沦的圣殿: 中国20世纪70年代地下诗歌遗照, ed. Liao Yiwu 廖亦武, 216-235. Urumqi: Xinjiang qingshaonian chubanshe.

Link, Perry. 2000. The Uses of Literature, Life in the Socialist Chinese Literary System. Princeton: Princeton University Press.

Ma, Bo. 1995. Blood Red Sunset: A Memoir of the Chinese Cultural Revolution, trans. Howard Goldblatt. New York: Penguin Viking.

MacFarquhar, Roderick, and Michael Schoenhals. 2006. Mao's Last Revolution. Cambridge: The Belknap Press of Harvard University Press.

McDougall, Bonnie S. 1980. Mao Zedong's "Talks at the Yan'an Conference on literature and art”. Ann Arbor: Center for Chinese Studies, University of Michigan.

McDougall, Bonnie S. (ed. \& trans.). 2000. Letters between Two: Correspondence between Lu Xun and Xu Guangping. Beijing: Foreign Languages Press.

McDougall, Bonnie S. 2002. Love Letters and Privacy in Modern China: The Intimate Lives of Lu Xun and Xu Guangping. Oxford: Oxford University Press.

Mittler, Barbara. 2012. A Continuous Revolution: Making Sense of Cultural Revolution Culture. Cambridge: Harvard University Press.

Moretti, Franco. 2007. Graphs Maps Trees: Abstract Models for Literary History. London: Verso.

Moretti, Franco. 2013. Distant Reading. London: Verso.

Mühlbach, Tabea. 2016. The Sword and the Pen: Lu Xun Endorsement in the Early Cultural Revolution. Seminar Paper: University of Freiburg.

Qi, Zhi 启之. 2011 Trivia at Beijing No. 4 High School 春色谁为主, 南北东 西路——四中琐记. Remembrance记忆 72. http://www.xujuneberlein.com/ rem72.html. Accessed 15 Dec 2016.

Seeger, Miriam. 2014. Zähmung der Flüsse: Staudämme und das Streben nach Produktiven Landschaften in China. Münster: LIT Verlag.

Sha, Mou 沙漠. 2010. Confessions of a Mother 一个母亲的忏悔. Yanhuang Chunqiu Zazhi炎黄春秋杂志 1. http://www.yhcqw.com/html/qsip/2010/ 19/1019165017EKDG76788IK6KDAD80B1FH1I.html. Accessed 10 Apr 2017.

Shao, Jiang. 2015. Citizen Publications before the Internet. New York: Palgrave Macmillan.

Shen, Zhanyun 沈展云. 2007. Grey-cover Books, Yellow-cover Books 灰皮书, 黄皮 书. Guangzhou: Huacheng chubanshe.

Shu, Ting 舒婷. 1999 (1980). Life, Books and Poems 生活、书籍与诗歌. In Sinking Holy Place: Death Pictures of Underground Poetry in China's 1970s 沉 沦的圣殿: 中国20世纪70年代地下诗歌遗照, ed. Liao Yiwu 廖亦武, 297-307. Urumqi: Xinjiang qingshaonian chubanshe.

Song, Yongyi, and 宋永毅. 1997. Yellow-Cover-Books and Grey-Cover-Books from the Cultural Revolution 文革中的黄皮书和灰皮书. Ershi Shiji 42: 5964. 
Song, Yongyi. 2007. A Glance at the Underground Reading Movement during the Cultural Revolution. Journal of Contemporary China 16 (51): 325-333.

Sun, Peidong, and 孙沛东. 2016. Socially Stratified Individual Reading of Beijing and Shanghai Educated Youth during the Cultural Revolution 文革时期京沪 知青阶层化的个人阅读. Ershiyi Shiji 156: 78-98.

Van Fleit Hang, Krista. 2013. Literature the People Love: Reading Chinese Texts from the Early Maoist Period (1949-1966). New York: Palgrave Macmillan.

Veg, Sebastian. 2019. Minjian: The Rise of China's Grassroots Intellectuals. New York: Columbia University Press.

Volland, Nicolai. 2003. The Control of the Media in the People's Republic of China. PhD diss., University of Heidelberg.

Volland, Nicolai. 2017a. Socialist Cosmopolitanism: The Chinese Literary Universe, 1945-1965. New York: Columbia University Press.

Volland, Nicolai. 2017b. Clandestine Cosmopolitanism: Foreign Literature in the People's Republic of China, 1957-1977. Journal of Asian Studies 76 (1): 185-210.

Wagner, Rudolf G. 1995. Life as a Quote from a Foreign Book: Love, Pavel, and Rita. In Das Andere China: Festschrift für Wolfgang Bauer zum 65. Geburtstag, ed. Helwig Schmidt-Glintzer, 463-476. Wiesbaden: Harrassowitz.

Wang, Shiqiang 王士强. 2014. The Origin of “Early Misty Poetry" in the 1960s and 1970s 1960-70年代“前朦胧诗”的发生探源. Yangzijiang pinglun 扬子 江评论 2: 74-80.

Wu, Hong 巫鸿. 2012. "Meeting by Chance": Memories of Books and the Reading in my Memories “不期而遇”: 对书的记忆与记忆中的读书. Dushu 读书 9: 116-125.

Xiao, Xiao 萧萧. 1999. The Course of Books: A Spirited Reading History 书的 轨道: 一部精神阅读史. In Sinking Holy Place: Death Pictures of Underground Poetry in China's 1970s 沉沦的圣殿: 中国20世纪70年代地下诗歌遗照, ed. Liao Yiwu 廖亦武, 4-16. Urumqi: Xinjiang qingshaonian chubanshe.

Xu, Xiao 徐晓. 1999a. Unnamed Events of the Past 無題往事. In Sinking Holy Place: Death Pictures of Underground Poetry in China's 1970s 沉沦的圣殿: 中国20世纪70年代地下诗歌遗照, ed. Liao Yiwu 廖亦武, 153-182, Urumqi: Xinjiang qingshaonian chubanshe.

Xu, Xiao 徐晓. 1999b. Today and I《今天》乡我. In Sinking Holy Place: Death Pictures of Underground Poetry in China's 1970s 沉沦的圣殿: 中国20世 纪70年代地下诗歌遗照, ed. Liao Yiwu 廖亦武, 379-414, Urumqi: Xinjiang qingshaonian chubanshe.

Yang, Guobin. 2003. China's Zhiqing Generation: Nostalgia, Identity, and Cultural Resistance in the 1990s. Modern China 29 (3): 267-296.

Yang, Guobin. 2005. Days of Old Are Not Puffs of Smoke: Three Hypotheses on Collective Memories of the Cultural Revolution. China Review 5 (2): 13-41.

Yang, Guobin. 2016. The Red Guard Generation and Political Activism in China. New York: Columbia University Press. 
Yang, Haosheng. 2016. A Modernity Set to a Premodern Tune: Classical Style Poetry of Modern Chinese Writers. Leiden: Brill.

Yang, Lan. 1998. Chinese Fiction of the Cultural Revolution. Hong Kong: Hong Kong University Press.

Yang, Yuping. 2013. Baudelaire et la Poésie Chinoise Souterraine au Temps de la Révolution Culturelle. Paris: Presses Sorbonne Nouvelle.

Ye, Weili, with Xiaodong Ma. 2005. Growing Up in the People's Republic: Conversations between Two Daughters of China's Revolution. New York: Palgrave Macmillan.

Yu, Min-Ling. 2002. A Soviet Hero, Pavel Korchagin, Comes to China. Russian History 29 (2/4): 329-355.

Zhang, Langlang 张朗朗. 2009. The Tranquil Horizon 宁静的地平线. In The Seventies 七十年代, ed. Bei Dao 北岛and Li Tuo 李陀，105-146. Beijing: Sanlian shudian.

Zhang, Yang 张扬. 1999. The Literary Inquisition of "The Second Handshake" 《 第二次握手》文字狱. Beijing: Zhongguo shehui chubanshe.

Zhao, Yuan 赵 园. 2016a. Reading in an Extraordinary Age (Part One) 非常年 代的阅读 (上). Shucheng 书城 3: 35-44.

Zhao, Yuan 赵园. 2016b. Reading in an Extraordinary Age (Part Two) 非常年 代的阅读 (下). Shucheng 书城 4: 20-29.

Zhongguo Banben Tushuguan 中国版本图书馆 (ed.). 1988. Comprehensive Table of Books Published in the National Internal Publishing System 全国内部发行图 书总目. Internal Publication. Beijing: Zhonghua Shuju.

Open Access This chapter is licensed under the terms of the Creative Commons Attribution 4.0 International License (http://creativecommons.org/licenses/ by $/ 4.0 /$ ), which permits use, sharing, adaptation, distribution and reproduction in any medium or format, as long as you give appropriate credit to the original author(s) and the source, provide a link to the Creative Commons license and indicate if changes were made.

The images or other third party material in this chapter are included in the chapter's Creative Commons licence, unless indicated otherwise in a credit line to the material. If material is not included in the chapter's Creative Commons licence and your intended use is not permitted by statutory regulation or exceeds the permitted use, you will need to obtain permission directly from the copyright holder.

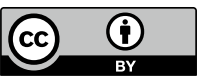

